\title{
Genetic divergence in basil cultivars and hybrids
}

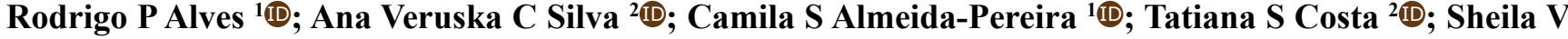 Alvares-Carvalho ${ }^{1} \mathbb{D}$; Maria de Fatima Arrigoni-Blank ${ }^{1} \mathbb{D}$; Arie F Blank ${ }^{1} \mathbb{D}$}

${ }^{1}$ Universidade Federal de Sergipe (UFS), São Cristóvão-SE, Brazil; rodrigo.pa07@gmail.com; camilaalmeida.agro@gmail.com; carvalhosva@ gmail.com; fatima.blank@gmail.com; arie.blank@gmail.com; ${ }^{2}$ Embrapa Tabuleiros Costeiros, Aracaju-SE, Brazil; ana.veruska@embrapa. br; tatianaitase@gmail.com

\section{ABSTRACT}

Basil is an aromatic herb that stands out for its economic importance. It is consumed in natura and used to obtain essential oil. The cultivation of this species in several regions of the world has allowed variations by natural crosses and euploidy, leading to the wide genetic variability found nowadays. Considering the importance of this species, we aimed to analyze the genetic diversity of 27 basil genotypes using ISSR molecular markers. Fourteen primers were employed for DNA amplification, resulting in $86 \%$ polymorphism. Based on the Jaccard's dissimilarity index, the highest index $(0.80)$ was observed between the individuals BAS001 and BAS012, while the lowest index (0.18) was detected between the genotypes BAS014 and BAS015. The genetic similarity among individuals was calculated, forming four distinct clusters. Most individuals $(40.7 \%)$ were allocated in cluster I. The polymorphic information content (PIC) (0.89) indicated considerable levels of genetic diversity among genotypes. In this sense, the ISSR markers were efficient in the detection of polymorphisms between the accessions, suggesting the genetic variability of the collection. This result demonstrates the importance of the use of molecular markers and the advantages that this information provides to the breeding of the species.

Keywords: Ocimum basilicum, diversity, molecular characterization, dominant marker.

\section{RESUMO}

Divergência genética observada entre cultivares e híbridos de manjericão

O manjericão é uma erva aromática que se destaca por possuir importância econômica. É consumido in natura e também utilizado na obtenção de óleo essencial. O cultivo desta espécie em diversas regiões do mundo permitiu que surgissem variações mediante cruzamentos naturais e euploidia, ocasionando a ampla variabilidade genética existente. Considerando a importância desta espécie, este trabalho teve como objetivo analisar a diversidade genética de 27 genótipos de manjericão usando marcadores moleculares ISSR. Quatorze primers foram utilizados para amplificação do DNA, resultando em $86 \%$ de polimorfismo. Com base no índice de dissimilaridade de Jaccard, observou-se o maior índice $(0,80)$ entre os indivíduos BAS001 e BAS012, enquanto que o menor índice de dissimilaridade $(0,18)$ foi detectado entre os genótipos BAS014 e BAS015. A semelhança genética entre indivíduos foi calculada, formando quatro grupos distintos. A maioria dos indivíduos $(40,7 \%)$ foi agrupada no grupo I. O conteúdo de informação polimórfica (PIC) $(0,89)$ indicou níveis consideráveis de diversidade genética entre os genótipos. Neste sentido, os marcadores ISSR foram eficientes na detecção de polimorfismos entre os acessos e confirmaram que é possível inferir a variabilidade genética na coleção. Isso demonstra a importância do uso de marcadores moleculares e as vantagens que esta informação pode oferecer ao melhoramento genético das espécies.

Palavras-chave: Ocimum basilicum, divergência, caracterização molecular, marcador dominante.

\section{Received on September 3, 2018; accepted on April 26, 2019}

$\mathrm{B}$ asil (Ocimum basilicum) belongs to the Lamiaceae family and originates from South-East Asia (India, Pakistan, Iran, Thailand, and other countries) and Central Africa (Makri \& Kintzios, 2008). The species has several culinary, ornamental, and aromatic uses (Blank et al., 2004). Besides the culinary use, basil has been traditionally employed as medicinal herb in the treatment of headaches, cough, diarrhea, constipation, warts, and/or kidney malfunction (Politeo et al., 2007). The global trade of basil in 2013 presented
China, India, Madagascar, Egypt, and Mexico as the major exporters. Conversely, the major importers were China, including Hong Kong, South Africa, USA, Germany, and Madagascar (FAO, 2017).

Due to the economic potential of medicinal and aromatic species, studies have increasingly focused on their germplasm characterization and conservation (Souza, 2015). Conservation of plant genetic resources ensures the maintenance of agrobiodiversity and provides farmers and plant breeders with options to develop, by selection and breeding, new and more productive crops, which are resistant to virulent pests and diseases and adapted to changing environments (Singh et al., 2017). The evaluation of diversity levels identifies parental combinations to create segregating progenies with maximum genetic variability and introduces desirable genes to the available genetic base (Samal et al., 2011).

Ocimum basilicum has distinct morphological diversity regarding its 
pigmentation, leaf shape, size, herbage, and oil yield (Saran et al., 2017). The agro-morphological characterization is the evaluation of all observable traits that could identify varieties or accessions in a collection, and it can be carried out in several forms, depending on the objectives (Moche et al., 2014). Cultivar identification based on phenotypic traits is usually influenced by the environment, which hinders the classification (Aghaei et al., 2012). Conversely, DNA fingerprinting with molecular markers allows precise, objective, and rapid cultivar identification, and has proven to be an efficient tool for germplasm characterization and management (Chakravarthi \& Naravaneni, 2006).

For breeders, the use of DNA markers to characterize varieties, lines, or hybrids has been of great importance since it allows verifying duplicity of accessions in germplasm collections, besides assisting in backcross programs (Borém, 2005; Melo et al., 2011). ISSR markers stand out among the techniques for DNA markers due to the advantages over other dominant markers, besides their greater applicability to genetic studies. ISSR markers are generated by microsatellite sequences, which are highly variable and distributed over the genome. ISSR markers have higher reproducibility when compared with RAPDs markers (Random Amplified Polymorphic DNA) and are cheaper than the AFLPs markers (Amplified Fragment Length Polymorphism) (Ng \& Tan, 2015). This technique has been used to estimate the genetic diversity in different medicinal and aromatic plants, such as Ocimum (Aghaei et al., 2012; Chen et al., 2013; Patel et al., 2015), Varronia curassavica (Brito et al., 2016), and Croton tetradenius (Almeida-Pereira et al., 2016).

In Brazil, basil breeding programs have been successfully conducted in the state of Sergipe, which is evidenced by the release of a new basil cultivar, Maria Bonita (high yield and essential oil content), and the hybrid Norine (rich in methyl cinnamate and linalool), both for cultivation in the Brazilian Northeast (Blank et al., 2007, 2015). Considering the importance of the subject under study, this work aimed to evaluate the genetic diversity among 27 basil genotypes, using ISSR markers.

\section{MATERIAL AND METHODS}

\section{Plant material}

Young leaves were sampled from plants collected at the Research Farm of Universidade Federal de Sergipe (UFS)", located in the municipality of São Cristovão, Sergipe, totaling 27 individuals. Out of these 27 individuals, 25 are commercial varieties, and two are hybrids produced in UFS (Table 1). During collection, leaves were stored in sterile gauze and kept on ice to prevent oxidation. Subsequently, all the collected material was stored in a freezer at $-80^{\circ} \mathrm{C}$ until DNA extraction.

\section{DNA extraction and PCR-ISSR} amplification

Approximately $1 \mathrm{~g}$ of each sample was subject to DNA extraction, based on the method described by Doyle \& Doyle (1990), modified by Alzate-Marin et al. (2009). After extraction, DNA was quantified using the Nanodrop 2000c spectrophotometer (Thermo Scientific, EUA), followed by DNA dilutions for further use in the PCR reactions. The quality of the extracted DNA was verified by $0.8 \%$ agarose gel horizontal electrophoresis. DNA samples were stored at $-20^{\circ} \mathrm{C}$.

Twenty-three ISSR primers were tested, but only fourteen showed polymorphism higher than $75 \%$; therefore, they were used to verify the genetic diversity of the 27 basil genotypes. The ISSR primers belonged to the University of British Columbia, Vancouver, Canada (Table 2). Each ISSR reaction was performed in a $12 \mu \mathrm{L}$ pre-sterile microtube containing 5.8 $\mu \mathrm{L}$ autoclaved ultrapure water, $1 \mu \mathrm{L}$ DNA genomic $(5 \mathrm{ng} / \mu \mathrm{L}), 0.2 \mu \mathrm{L}$ Taq polymerase (Ludwig Biotec, Brasil-RS) (5 U/ $\mu \mathrm{L}), 2 \mu \mathrm{L} 10 \mathrm{x}$ buffer $(100 \mathrm{mM}$ Tris-HCl, pH 8.5, $500 \mathrm{mM} \mathrm{KCl),} 0.6$ $\mu \mathrm{L} \mathrm{MgCl}_{2}(50 \mathrm{mM})$ (Ludwig Biotec, Brasil-RS), 0.4 $\mu \mathrm{L} \mathrm{dNTP} \mathrm{(2.5} \mathrm{mM),} \mathrm{and}$ $2.0 \mu \mathrm{L}$ primer $(25.0 \mathrm{pmol})$.

The ProFlex PCR System (Thermo Fisher Scientific, Applied Biosystems, Foster City, CA, USA) was used for DNA amplification, which was programmed with initial denaturation at $95^{\circ} \mathrm{C}$ for 5 minutes; followed by 35 amplification cycles. In each cycle, samples were subject to denaturation at $94^{\circ} \mathrm{C}$ for 40 seconds; annealing at different temperatures (depending on the optimum temperature of the primer used) for 1 minute; and extension at $72^{\circ} \mathrm{C}$ for 1 minute. After the reactions cycle, a final extension was carried out at $72^{\circ} \mathrm{C}$ for 7 minutes.

Afterward, the products were subject to $2.0 \%$ agarose gel horizontal electrophoresis. The $100 \mathrm{bp}$ ladder (Ludwig Biotec, Brasil-RS) was used as a molecular weight standard. Subsequently, the agarose gels were stained with ethidium bromide solution $(0.5 \mu \mathrm{L} / \mathrm{mL})$ for the visualization of the DNA fragments under ultraviolet light, and then photo-documented by the Gel doc L-pix device (Loccus Biotecnologia, Cotia-SP).

\section{Data analysis}

PCR-ISSR amplification products on agarose gel were analyzed for all the primers used in this study, generating a binary matrix based on the presence (1) and absence (0) of bands. All analyses used this matrix to study the genetic diversity of basil genotypes. Percentage of polymorphic bands (PBP) was obtained by the Genalex 6.5 software (Peakall \& Smouse, 2012). Polymorphic Information Content (PIC) and values of correlation and stress were estimated using the GENES software (Cruz, 2016).

Genetic diversity among individuals was calculated using the Jaccard's distance. The dendrogram and the Bootstrap analysis for 10.000 simulations were constructed by the GENES software (Cruz, 2016), based on the genetic dissimilarity index, using the Ward method. The structure of the population and the identification of admixed individuals were performed using the software Structure, version 2.3.4 (Pritchard et al., 2000). The software uses the Bayesian clustering method and assumes the distance of $\mathrm{K}$ populations (in which $\mathrm{K}$ may be unknown), and each one of these populations is characterized by a set of allele frequencies for each locus. To determine the number of clusters $(\mathrm{K})$ in the samples, the values $\mathrm{K}=2$ to $\mathrm{K}=$ 
12 were assigned, and five independent analyses were performed for each value of $\mathrm{K}$. The admixture ancestry model was used, and the results were based on 100.000 simulations with burn-in of 10.000. The $\Delta \mathrm{K}$ value was used to select the ideal number of clusters (Evanno et al., 2005). This value was estimated using the Structure Harvester software (Earl \& von Holdt, 2012).

\section{RESULTS AND DISCUSSION}

The genetic variability of 27 basil genotypes was estimated using 14 ISSR primers, totaling 147 amplified fragments, of which $86 \%$, on average, were polymorphic. The number of amplified fragments varied from eight (UBC 860) to 14 (UBC 841) bands per primer, totaling a mean of 10.5 bands per primer (Table 2).
Primers UBC 823, UBC 827, UBC 841, UBC 861, and UBC 862 had the highest percentage of polymorphic bands (above 90\%), comprising 54 of 127 amplified polymorphic bands, and were responsible for $42 \%$ of the polymorphism generated (Table 2).

Correlation estimates between basil genotypes were high (0.999), confirming the stability of the number of selected primers and fragments obtained. Also, the stress value $(0.007)$ was lower than 0.05 , which indicates the reliability of the results (Kruskal, 1964).

The efficiency of the ISSR molecular marker has been proven in the present study and in several other works on genetic diversity, such as those that analyzed species of the genus Ocimum (Aghaei et al., 2012; Chen et al., 2013; Patel et al., 2015) and other medicinal and aromatic species [e.g., Croton tetradenius (Almeida-Pereira et al., 2016) and Varronia curassavica (Brito et al., 2016)].

The PIC value was 0.89 , which is considered as highly informative, according to Botstein et al. (1980). Therefore, ISSR markers were considered as informative in the evaluation of the genetic diversity of basil genotypes and reproduced polymorphism suitable for the analyses. The molecular size of the bands ranged from 50 to $1000 \mathrm{bp}$, and several specific bands were identified (Table 2).

Patel et al. (2015) demonstrated the effectiveness of dominant markers using 12 ISSR primers in a study with five species of the genus Ocimum ( $O$. basilicum, $O$. americanum, $O$. sanctum, $O$. gratissimum, and $O$. polystachyon). Their results totaled 238 fragments with $98.17 \%$ polymorphism and high mean

Table 1. Identification of the 27 basil genotypes evaluated. São Cristovão, UFS, 2017.

\begin{tabular}{|c|c|c|c|}
\hline Code & Cultivar/hybrid & Scientific name & Origin/Company \\
\hline BAS001 & Anise & Ocimum basilicum & Richters \\
\hline BAS002 & Ararat & Ocimum basilicum & Richters \\
\hline BAS003 & Cinnamon & Ocimum basilicum & Richters \\
\hline BAS004 & Dark Opal & Ocimum basilicum & Richters \\
\hline BAS005 & Edwina & Ocimum basilicum & Richters \\
\hline BAS006 & Elidia & Ocimum basilicum & Richters \\
\hline BAS007 & Envigor & Ocimum basilicum & Richters \\
\hline BAS008 & Gecofure & Ocimum basilicum & Richters \\
\hline BAS009 & Genovese & Ocimum basilicum & Richters \\
\hline BAS010 & Green Globe & Ocimum basilicum & Richters \\
\hline BAS011 & Italian Large Leaf & Ocimum basilicum & Richters \\
\hline BAS012 & Magical Michael & Ocimum basilicum & Richters \\
\hline BAS013 & Mrs. Burns & Ocimum basilicum & Richters \\
\hline BAS014 & Napoletano & Ocimum basilicum & Richters \\
\hline BAS015 & Nufar F1 & Ocimum basilicum & Richters \\
\hline BAS016 & Osmin & Ocimum basilicum & Richters \\
\hline BAS017 & Purple Ruffles & Ocimum basilicum & Richters \\
\hline BAS018 & Red Genovese & Ocimum basilicum & Richters \\
\hline BAS019 & Sweet Dani & Ocimum $x$ citriodorum & Richters \\
\hline BAS020 & Grecco a Palla & Ocimum basilicum & ISLA ( $\left.n^{\circ} 479\right)$ \\
\hline BAS021 & Italian Large Leaf & Ocimum basilicum & ISLA ( $\left.n^{\circ} 488\right)$ \\
\hline BAS022 & Italian Large Red Leaf & Ocimum basilicum & ISLA ( $\left.n^{\circ} 489\right)$ \\
\hline BAS023 & Limoncino & Ocimum basilicum & ISLA ( $\left.n^{\circ} 499\right)$ \\
\hline BAS024 & Red Rubin Purple Leaf & Ocimum basilicum & $\operatorname{ISLA}\left(n^{\circ} 491\right)$ \\
\hline BAS025 & Maria Bonita & Ocimum basilicum & UFS \\
\hline BAS026 & Sweet Dani x Genovese & Ocimum basilicum & Hybrid 1 \\
\hline BAS027 & Cinnamon x Maria Bonita & Ocimum basilicum & Hybrid 2 \\
\hline
\end{tabular}


value of PIC (0.92), which evidences the high genetic diversity and corroborates the result observed in the present study $(\mathrm{PIC}=0.89)$. Aghaei et al. $(2012)$ also reported high similarity values (0.601.00) for the genetic diversity of Iranian basil (Ocimum basilicum) using ISSR markers.
Based on the Jaccard's similarity index, the highest dissimilarity value among the 27 basil genotypes was 0.80 for individuals BAS001 (Anise) and

Table 2. Annealing temperature, primers sequence, and amplified products used for the analysis of the genetic diversity of basil genotypes. São Cristovão, UFS, 2017.

\begin{tabular}{lcccccc}
\hline Primer & Sequence (5'-3') & $\begin{array}{c}\text { Length } \\
\text { (bp) }\end{array}$ & $\begin{array}{c}\text { Annealing } \\
\text { temperature }\left({ }^{\circ} \mathrm{C}\right)\end{array}$ & $\begin{array}{c}\text { Total } \\
\text { bands }\end{array}$ & $\begin{array}{c}\text { Polymorphic } \\
\text { bands }\end{array}$ & $\begin{array}{c}\text { Polymorphism } \\
(\mathbf{\%})\end{array}$ \\
\hline UBC810 & GAG AGA GAG AGA GAG AT & $50-500$ & 54.8 & 11 & 9 & 81.8 \\
UBC811 & GAG AGA GAG AGA GAG AC & $150-650$ & 46.8 & 9 & 7 & 77.8 \\
UBC813 & CTC TCT CTC TCT CTC TT & $200-750$ & 44.6 & 9 & 8 & 88.9 \\
UBC815 & CTC TTC TCT CTC TCT CTG & $200-900$ & 47.6 & 9 & 7 & 77.8 \\
UBC823 & TCT CTC TCT CTC TCT CC & $150-750$ & 57.2 & 10 & 10 & 100.0 \\
UBC827 & ACA CAC ACA CAC ACA CG & $100-750$ & 57.2 & 10 & 9 & 90.0 \\
UBC835 & AGA GAG AGA GAG AGA GYC & $50-900$ & 58.8 & 11 & 9 & 81.8 \\
UBC841 & GAG AGA GAG AGA GAG AYC & $50-600$ & 58.8 & 14 & 13 & 92.9 \\
UBC856 & ACA CAC ACA CAC ACA CYA & $100-750$ & 56.5 & 12 & 10 & 83.3 \\
UBC857 & ACA CAC ACA CAC ACY G & $100-900$ & 58.8 & 9 & 7 & 77.8 \\
UBC860 & TGT GTG TGT GTG TGT GRA & $200-750$ & 46.9 & 8 & 7 & 87.5 \\
UBC861 & ACC ACCACCACCACCACC & $150-1000$ & 64.5 & 13 & 12 & 92.3 \\
UBC862 & AGC AGCAGCAGCAGCAGC & $100-1000$ & 64.5 & 11 & 10 & 90.9 \\
UBC866 & CTC CTCCTCCTCCTCCTC & $250-900$ & 55.7 & 11 & 9 & 81.8 \\
\hline Total & \multicolumn{7}{r}{} & 147 & 127 & 86.0 \\
\hline
\end{tabular}

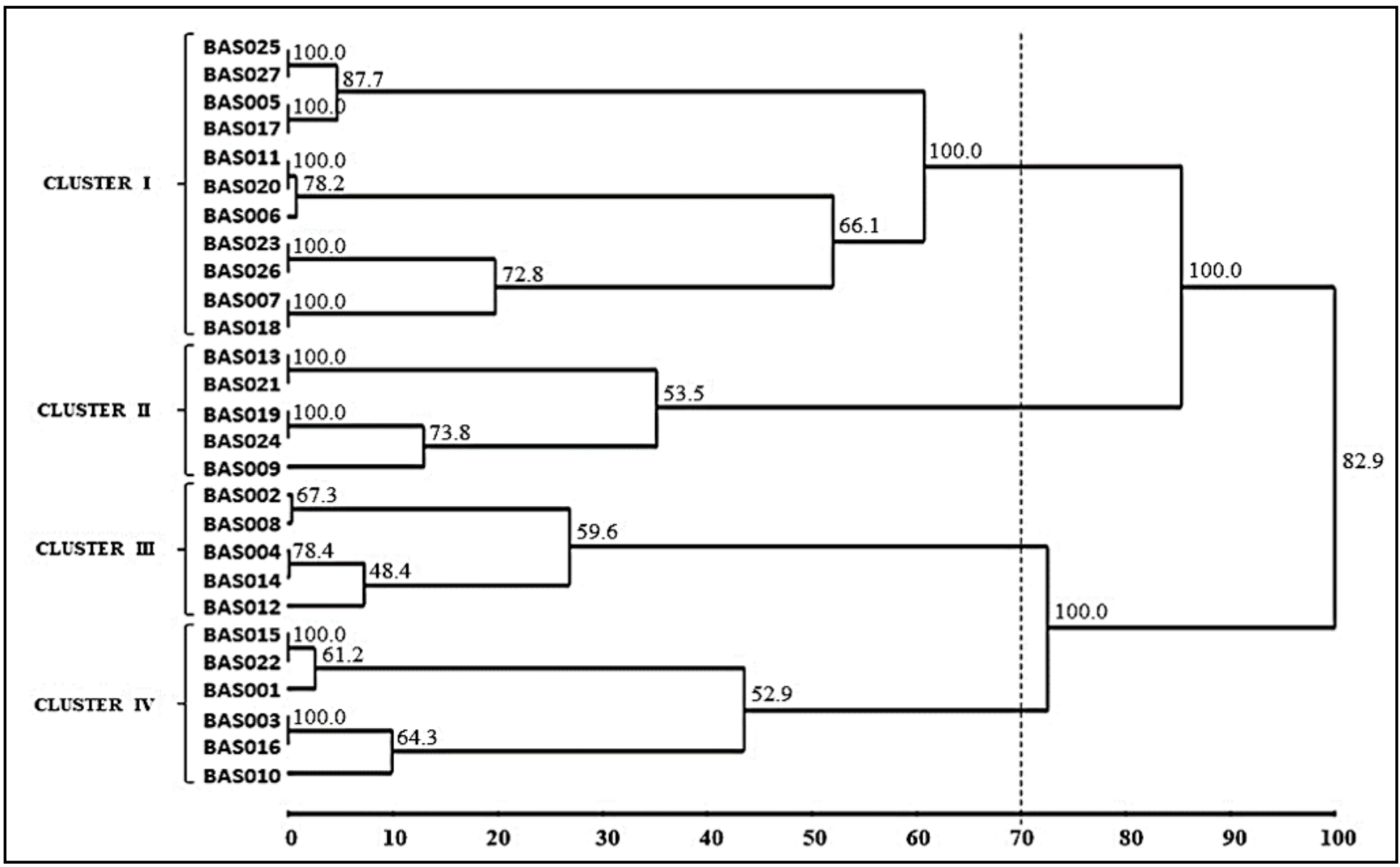

Figure 1. Dendrogram obtained by the WARD method, based on the genetic dissimilarity index by the Jaccard's similarity index, for 27 basil genotypes. São Cristovão, UFS, 2017. 
Table 3. Jaccard's dissimilarity index using 14 primers by the ISSR technique among 27 basil genotypes. São Cristovão, UFS, 2017.

\begin{tabular}{|c|c|c|c|c|c|c|c|c|c|c|c|c|c|c|c|c|c|c|c|c|c|c|c|c|c|c|}
\hline \multirow[b]{2}{*}{ Plant } & \multicolumn{26}{|c|}{ Plant (BAS) } \\
\hline & 001 & 002 & 003 & 004 & 005 & 006 & 007 & 008 & 009 & 010 & 011 & 012 & 013 & 014 & 015 & 016 & 017 & 018 & 019 & 020 & 021 & 022 & 023 & 024 & 025 & 026 \\
\hline BAS002 & 0.56 & & & & & & & & & & & & & & & & & & & & & & & & & \\
\hline BAS003 & 0.56 & 0.34 & & & & & & & & & & & & & & & & & & & & & & & & \\
\hline BAS004 & 0.54 & 0.34 & 0.30 & & & & & & & & & & & & & & & & & & & & & & & \\
\hline BAS005 & 0.54 & 0.38 & 0.25 & 0.26 & & & & & & & & & & & & & & & & & & & & & & \\
\hline BAS006 & 0.51 & 0.41 & 0.39 & 0.42 & 0.28 & & & & & & & & & & & & & & & & & & & & & \\
\hline BAS007 & 0.48 & 0.35 & 0.32 & 0.34 & 0.24 & 0.28 & & & & & & & & & & & & & & & & & & & & \\
\hline BAS008 & 0.52 & 0.37 & 0.34 & 0.38 & 0.28 & 0.35 & 0.22 & & & & & & & & & & & & & & & & & & & \\
\hline BAS009 & 0.55 & 0.39 & 0.31 & 0.31 & 0.27 & 0.31 & 0.27 & 0.23 & & & & & & & & & & & & & & & & & & \\
\hline BAS010 & 0.57 & 0.50 & 0.45 & 0.46 & 0.40 & 0.36 & 0.29 & 0.36 & 0.33 & & & & & & & & & & & & & & & & & \\
\hline BAS011 & 0.55 & 0.46 & 0.41 & 0.39 & 0.26 & 0.30 & 0.27 & 0.29 & 0.31 & 0.26 & & & & & & & & & & & & & & & & \\
\hline BAS012 & 0.80 & 0.49 & 0.45 & 0.43 & 0.53 & 0.54 & 0.47 & 0.51 & 0.51 & 0.52 & 0.52 & & & & & & & & & & & & & & & \\
\hline BAS013 & 0.62 & \begin{tabular}{c}
0.46 \\
\hdashline$\ldots . . . .1$ \\
$\vdots$
\end{tabular} & 0.42 & \begin{tabular}{l}
0.36 \\
\hdashline$\ldots . . . . .$. \\
\end{tabular} & $\begin{array}{c}0.43 \\
\ldots . . .1 . . . \\
\end{array}$ & $\begin{array}{l}0.50 \\
\ldots \ldots \ldots\end{array}$ & $\begin{array}{c}0.48 \\
\ldots \ldots \ldots\end{array}$ & $\begin{array}{c}0.40 \\
\ldots \ldots \ldots\end{array}$ & $\begin{array}{c}0.48 \\
\ldots \ldots . .\end{array}$ & 0.51 & $\begin{array}{c}0.43 \\
\ldots \ldots \ldots\end{array}$ & 0.52 & & & & & & & & & & & & & & \\
\hline BAS014 & 0.56 & 0.35 & 0.40 & 0.31 & 0.34 & 0.43 & 0.33 & 0.41 & 0.38 & 0.45 & 0.40 & 0.53 & 0.41 & & & & & & & & & & & & & \\
\hline BAS015 & 0.57 & 0.34 & 0.28 & 0.22 & 0.26 & 0.42 & 0.24 & 0.31 & 0.30 & 0.40 & 0.34 & 0.44 & 0.41 & 0.18 & & & & & & & & & & & & \\
\hline BAS016 & 0.54 & 0.41 & 0.44 & 0.40 & 0.40 & $\begin{array}{l}0.39 \\
\ldots \ldots \ldots\end{array}$ & $\begin{array}{c}0.40 \\
\ldots \ldots \ldots\end{array}$ & $\begin{array}{c}0.46 \\
\ldots \ldots \ldots\end{array}$ & $\begin{array}{c}0.36 \\
\ldots \ldots \ldots\end{array}$ & $\begin{array}{c}0.45 \\
\ldots \ldots \ldots\end{array}$ & 0.44 & 0.47 & 0.45 & 0.35 & 0.33 & & & & & & & & & & & \\
\hline BAS017 & 0.67 & 0.40 & 0.36 & 0.40 & $\begin{array}{c}0.36 \\
\ldots \ldots \ldots \ldots\end{array}$ & 0.45 & 0.36 & 0.35 & 0.41 & 0.43 & 0.41 & 0.51 & 0.47 & 0.34 & 0.24 & 0.40 & & & & & & & & & & \\
\hline BAS018 & 0.60 & 0.42 & 0.35 & 0.33 & 0.39 & $\begin{array}{l}0.45 \\
\ldots \ldots \ldots\end{array}$ & $\begin{array}{c}0.41 \\
\ldots \ldots \ldots\end{array}$ & $\begin{array}{c}0.46 \\
\ldots \ldots \ldots\end{array}$ & $\begin{array}{c}0.40 \\
\ldots \ldots \ldots\end{array}$ & $\begin{array}{c}0.46 \\
\ldots \ldots \ldots\end{array}$ & 0.43 & 0.48 & 0.46 & 0.34 & 0.31 & 0.38 & 0.29 & & & & & & & & & \\
\hline BAS019 & 0.65 & 0.50 & 0.46 & 0.44 & 0.48 & 0.54 & 0.47 & 0.51 & 0.48 & 0.53 & 0.47 & 0.57 & 0.39 & 0.47 & 0.47 & 0.52 & 0.43 & 0.41 & & & & & & & & \\
\hline BAS020 & 0.62 & $0.52 \vdots$ & 0.39 & \begin{tabular}{c}
0.46 \\
\hdashline$\ldots . . . .$. \\
\end{tabular} & 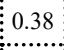 & \begin{tabular}{l}
0.42 \\
\hdashline$\ldots . .$.
\end{tabular} & $\begin{array}{l}0.43 \\
\ldots \ldots \ldots . . .\end{array}$ & $\begin{array}{c}0.46 \\
\ldots \ldots \ldots\end{array}$ & $\begin{array}{c}0.44 \\
\ldots \ldots \ldots\end{array}$ & $\begin{array}{l}0.37 \\
\ldots \ldots \ldots\end{array}$ & 0.34 & 0.52 & 0.48 & 0.46 & 0.43 & 0.51 & 0.44 & 0.38 & \begin{tabular}{l}
0.44 \\
\hdashline$\ldots \ldots . .$. \\
\end{tabular} & & & & & & & \\
\hline $\begin{array}{l}\text { BAS021 } \\
\ldots \ldots \ldots \ldots \ldots \ldots\end{array}$ & 0.57 & 0.40 & 0.34 & 0.36 & 0.26 & 0.38 & 0.24 & 0.35 & 0.36 & 0.41 & 0.33 & 0.46 & 0.46 & 0.34 & 0.27 & 0.46 & 0.37 & 0.35 & 0.40 & 0.40 & & & & & & \\
\hline 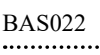 & 0.59 & \begin{tabular}{l}
0.45 \\
\hdashline$\ldots \ldots . .$. \\
$\ldots y$
\end{tabular} & 0.38 & 0.36 & 0.32 & 0.40 & 0.30 & 0.37 & 0.38 & 0.44 & 0.33 & 0.42 & 0.50 & 0.35 & 0.29 & 0.41 & 0.41 & 0.32 & 0.48 & 0.41 & 0.24 & & & & & \\
\hline $\begin{array}{l}\text { BAS023 } \\
\ldots \ldots \ldots \ldots \ldots \ldots\end{array}$ & 0.59 & 0.44 & 0.43 & 0.38 & 0.43 & 0.48 & 0.44 & 0.45 & 0.45 & 0.55 & 0.47 & 0.53 & 0.40 & 0.44 & 0.42 & 0.54 & 0.44 & 0.47 & 0.34 & 0.50 & 0.41 & 0.46 & & & & \\
\hline BAS024 & 0.52 & $\begin{array}{c}0.41 \\
\vdots \ldots . . . . . \\
\end{array}$ & 0.39 & 0.33 & \begin{tabular}{l}
0.35 \\
\hdashline$\ldots \ldots . .$. \\
\end{tabular} & 0.32 & $\begin{array}{c}0.36 \\
0 . . \cdots\end{array}$ & $\begin{array}{c}0.37 \\
\ldots \ldots \ldots\end{array}$ & $\begin{array}{c}0.33 \\
\ldots \ldots \ldots\end{array}$ & $\begin{array}{l}0.42 \\
\vdots \ldots \ldots \ldots\end{array}$ & $\begin{array}{l}0.39 \\
\vdots \ldots \ldots \ldots\end{array}$ & 0.45 & 0.43 & 0.35 & 0.33 & \begin{tabular}{l}
0.32 \\
\hdashline$\ldots \ldots . .$.
\end{tabular} & 0.36 & 0.38 & \begin{tabular}{l}
0.44 \\
\hdashline$\ldots \ldots . .$.
\end{tabular} & $0.42 \vdots$ & \begin{tabular}{l}
0.33 \\
\hdashline$\ldots \ldots .$.
\end{tabular} & $\begin{array}{c}0.38 \\
\vdots \ldots . . . . . \\
\vdots\end{array}$ & 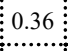 & & & \\
\hline BAS025 & 0.60 & 0.39 & 0.35 & 0.36 & 0.31 & 0.37 & 0.35 & 0.37 & $\begin{array}{l}0.34 \\
\vdots\end{array}$ & $\begin{array}{l}0.48 \\
\vdots\end{array}$ & 0.42 & $\begin{array}{l}\vdots \\
\vdots\end{array} 0.51 \vdots$ & 0.41 & 0.39 & 0.33 & 0.45 & 0.36 & 0.41 & 0.44 & 0.43 & 0.32 & $0.39 \vdots$ & $\begin{array}{l}\vdots \\
\vdots\end{array} 0.39 \vdots$ & 0.26 & & \\
\hline BAS026 & 0.48 & 0.48 & 0.49 & \begin{tabular}{l}
0.44 \\
\hdashline$\ldots \ldots . . .$. \\
\end{tabular} & 0.47 & \begin{tabular}{l}
0.50 \\
\hdashline$\ldots \ldots . .$. \\
\end{tabular} & $\begin{array}{c}0.49 \\
\ldots \ldots \ldots\end{array}$ & $\begin{array}{c}0.54 \\
\ldots \ldots \ldots\end{array}$ & $\begin{array}{c}0.44 \\
\ldots \ldots \ldots\end{array}$ & $\begin{array}{c}0.51 \\
\ldots \ldots \ldots\end{array}$ & \begin{tabular}{l}
0.52 \\
\hdashline$\ldots \ldots . .$.
\end{tabular} & 0.55 & 0.42 & 0.52 & 0.51 & 0.52 & 0.56 & 0.50 & 0.41 & 0.50 & \begin{tabular}{l}
0.49 \\
\hdashline$\ldots \ldots . .$.
\end{tabular} & $0.54 \vdots$ & 0.40 & 0.42 & 0.35 & \\
\hline BAS027 & 0.54 & 0.43 & 0.42 & 0.32 & 0.40 & 0.46 & 0.45 & 0.46 & 0.39 & 0.52 & 0.46 & 0.53 & 0.35 & 0.45 & 0.44 & 0.47 & 0.46 & 0.35 & 0.38 & 0.44 & 0.43 & 0.44 & 0.36 & 0.40 & 0.36 & 0.34 \\
\hline
\end{tabular}

BAS012 (Magical Michael), indicating higher genetic diversity between these individuals (Table 3 ). This fact can be explained by the geographical distance between the place of origin of both species since cultivar Anise comes from Iran, and Magical Michael originates from North America. Genotypes BAS014 (Napoletano) and BAS015 (Nufar F1) formed the pair with the lowest genetic dissimilarity index (0.18) (Table 3), suggesting a closer genetic relationship between each other (Sayed et al., 2009). The study describing the variability and/or genetic diversity of individuals within and between populations is mandatory for the genetic characterization of species. This characterization is a common procedure in the conservation of natural resources and breeding programs (White et al., 2018).
The number of clusters $(\mathrm{K})$ was identified based on the maximum likelihood and $\Delta \mathrm{K}$ values. For the 27 basil genotypes, the maximum $\Delta \mathrm{K}$ was observed for $\mathrm{K}=4$, and genotypes were separated into four clusters. The genetic diversity between individuals was calculated based on the Jaccard's dissimilarity index, using the Ward method, resulting in four distinct clusters when the mean distance cut-off point was of approximately 0.70 . Cluster I was represented by the individuals BAS005, BAS006, BAS007, BAS011, BAS017, BAS018, BAS020, BAS023, BAS025, BAS026, and BAS027 (Figure 1). Genotypes BAS025 (Maria Bonita) and BAS027 (Cinnamon x Maria Bonita hybrid) were included in group 1 , and they are respectively the genitor and progeny, which shows the genetic proximity between them. Also, the cluster has the highest number of cultivars of Italian origin, such as Edwina (BAS005), Elidia (BAS006), Envigor (BAS007), Italian Large Leaf (BAS011), and Red Genovese (BAS018). The clustering of a large number of genotypes revealed low genetic variability, which may be due to the autogamous propagation of basil. This fact reduces the genetic variability and the biodiversity in cultivars used in agriculture since farmers utilize fewer genotypes for seed production. Cluster II was represented by the individuals BAS009, BAS013, BAS019, BAS021, and BAS024. Genotypes Ms. Burns (BAS013) and Sweet Dani (BAS019) were possibly inserted in this cluster since they have geranial and neral as the major compounds (Pinto et al., 2018). Genotypes Genovese (BAS009), Italian Large Leaf (BAS021), and 


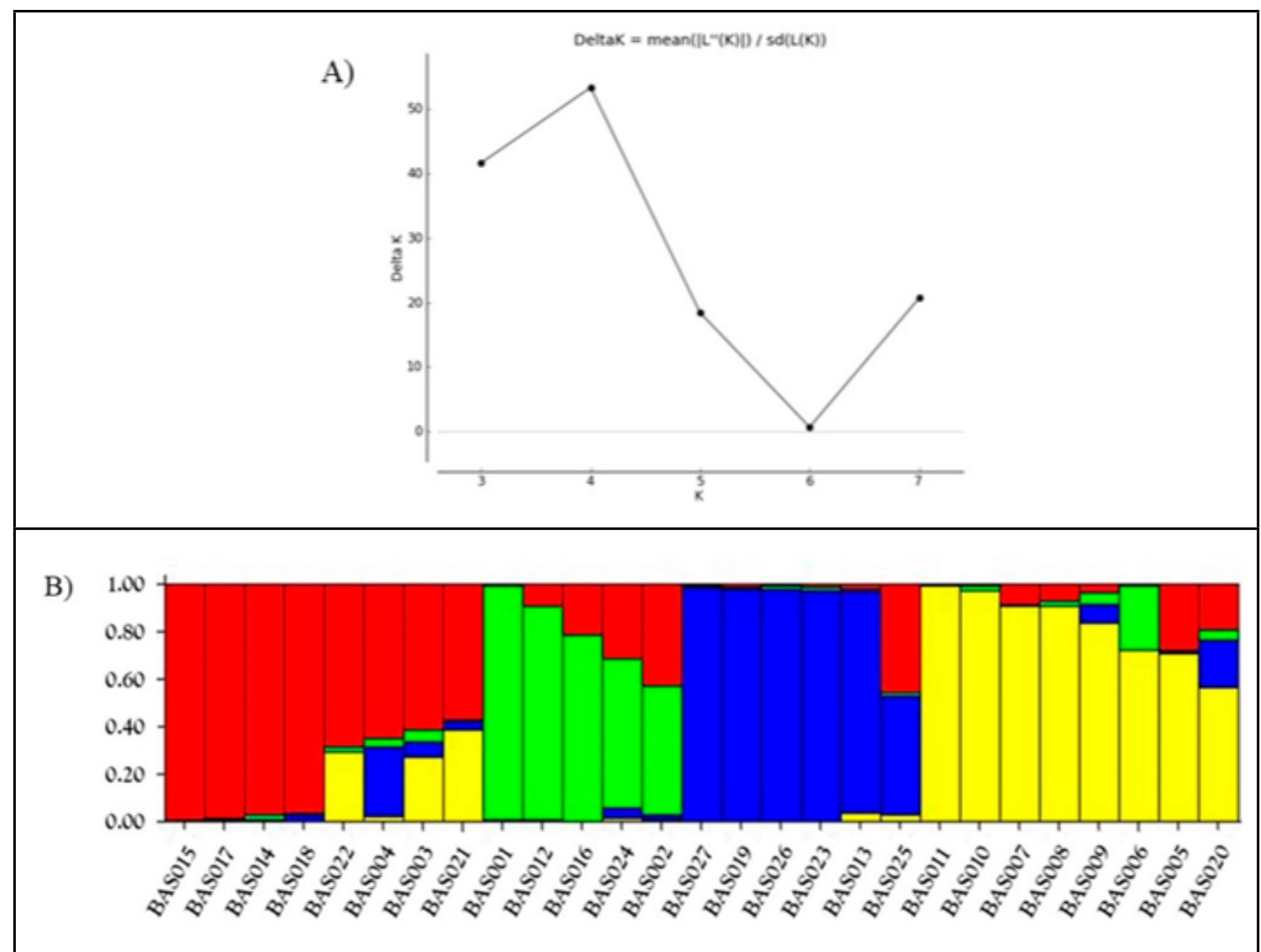

Figure 2. STRUCTURE analysis of the number of populations for K (A), and Bayesian clustering results with $\mathrm{K}=4$ of 27 basil genotypes (B). São Cristovão, UFS, 2017.

Red Rubin (BAS024) were allocated in the same cluster since they had linalool and 1,8-cineole as the major compounds (Costa et al., 2015). Cluster III was represented by the individuals BAS002, BAS004, BAS008, BAS012, and BAS014. This cluster included cultivars that showed high linalool concentrations, such as Dark Opal (BAS004), Magical Michael (BAS012), and Napoletano (BAS014) (Pinto et al., 2018). Cluster IV was represented by individuals BAS001, BAS003, BAS010, BAS015, BAS016, and BAS022. Cultivars Anise (BAS001), Cinnamon (BAS003), Green Globe (BAS010), and Nufar F1 (BAS015), allocated in cluster IV, had also been clustered together in another research that evaluated the genetic diversity among Ocimum species (Chen et al., 2013).

The Bayesian cluster analysis divided the population into four clusters defined by the colors red, green, blue, and yellow (Figure 2). This analysis revealed similar clusters to those of the WARD method. Genotypes BAS003 (Cinnamon), BAS004 (Osmin), BAS009 (Genovese), BAS020 (Grecco a Palla), BAS024 (Red Rubin Purple Leaf), and BAS025 (Maria Bonita) were the only ones that had the four colors. This result indicates that these plants should be prioritized for preservation since they may be useful in future studies aimed at the genetic breeding of the species. The analysis of plant diversity is fundamental for the germplasm curator as it helps define the variation structure, and thus enable the assessment of genetic erosion, potential exploration, and the priorities for the germplasm conservation (Ojo et al., 2012). Conservation helps maintain the genetic base, which is necessary for breeding.
During the conservation process, better varieties and crop lines can be selected for food, fuel, and medicine. The leaves and oil of Ocimum have many medicinal properties and are highly demanded by the industry. Thus, its cultivation proves to be a good source of income to farmers. The characteristics of the crop, such as short cycle, high biomass production, and suitability to tropical and sub-tropical areas are advantages for large scale production. Moreover, its high cross-pollination provides a high chance for the development of new chemotypes with a unique essential oil profile (Srivastava et al., 2018).

The knowledge of the reproductive system of the species of interest is fundamental since it can influence the genetic variability, either by homogenizing or increasing the divergence between individuals and populations (Zanella et al., 2012). 
Several other autogamous species had their genetic diversity reduced. This fact might be due to the domestication process, which occurred away from the species' center of origin. Also, it might have been influenced by the genetic breeding the species underwent over the years, which is based on a limited number of genotypes (Saavedra et al., 2001). Therefore, the study on the genetic diversity can assist the analysis of the genetic variability of cultivars and identify possible parental combinations for the obtainment of segregating progenies and the introduction of desirable genes (Samal et al., 2011).

The ISSR markers efficiently determined the genetic variation and genetic relationships in basil. The study on the genetic diversity of the selected individuals is paramount for contributing to the knowledge of the species and allowing the selection of genotypes to be included in future breeding programs.

\section{ACKNOWLEDGMENTS}

This study was financed in part by Conselho Nacional de Desenvolvimento Científico e Tecnológico (CNPq), Fundação de Apoio à Pesquisa e a Inovação Tecnológica do Estado de Sergipe (FAPITEC/SE), Coordenação de Aperfeiçoamento de Pessoal de Nível Superior (CAPES - Finance Code 001), and Financiadora de Estudos e Projetos (FINEP).

\section{REFERENCES}

AGHAEI, M; DARVISHZADEH, R; HASSANI, A. 2012. Molecular characterization and similarity relationships among Iranian basil (O. basilicum) accessions using Inter Simple Sequence Repeat markers. Revista Ciência Agronômica 43: 312-320.

ALMEIDA-PEREIRA, CS; SILVA, AVC; ALVES, RP; FEITOSA-ALCANTARA, RB; ARRIGONI-BLANK, MF; ALVARESCARVALHO, SV; COSTA, TS; WHITE, LAS; PINTO, VS; SAMPAIO, TS; BLANK, AF. 2016. Genetic diversity of native populations of Croton tetradenius Baill. using ISSR markers. Genetics and Molecular Research 16: 1-12.

ALZATE-MARIN, AL; GUIDUGLI, MC; SORIANI, HH; MARTINEZ, CA; MESTRINER, MA. 2009. An efficient and rapid DNA minipreparation procedure suitable for PCR/SSR and RAPD analyses in tropical forest tree species. Brazilian Archives of Biology and Technology 5: 1217-1224.

BLANK, AF; CARVALHO FILHO, JLS; SANTOS NETO, AL; ALVES, PB; ARRIGONI-BLANK, MF; SILVA-MANN, R; MENDONÇA, MC. 2004. Caracterização morfológica e agronômica de acessos de manjericão e alfavaca. Horticultura Brasileira 22: 113-116.

BLANK, AF; SANTANA, ADD; ARRIGONIBLANK, MF; ANDRADE, TM; PINTO, JAO; NASCIMENTO JÚNIOR, AF; LUZ, JMQ. 2015. 'Norine,' a cinnamon-linalool hybrid cultivar of basil. Crop Breeding and Applied Biotechnology 15: 285-289.

BLANK, AF; SOUZA, EM; ARRIGONIBLANK, MF; PAULA, JWA; ALVES, PB.2007. Maria Bonita: cultivar de manjericão tipo linalol. Pesquisa Agropecuéria Brasileira 42: 1811-1813.

BORÉM, A. 2005. Melhoramento de espécies cultivadas. Viçosa: UFV, 969p.

BOTSTEIN, D; WHITE, RL; SKOLNICK, M; DAVIS, RW.1980. Construction of a genetic linkage map in man using restriction fragment length polymorphisms. American Journal of Human Genetics 32: 314-331.

BRITO, FA; NIZIO, DAC; SILVA, AVC; DINIZ, LEC; RABBANI, ARC; ARRIGONIBLANK, MF; ALVARES-CARVALHO, SV; FIGUEIRA, GM; MONTANARI JÚNIOR, I; BLANK, AF. 2016. Genetic diversity analysis of Varronia curassavica Jacq. accessions using ISSR markers.Genetics and Molecular Research 15: 1-10.

CHAKRAVARTHI, BK; NARAVANENI, R. 2006. SSR marker based DNA fingerprinting and diversity study in rice (Oryza stativa L.). African Journal of Biotechnology 5: 684-988.

CHENSY, DAITX; CHANG, YT; WANG, SS; OU, SL; CHUANG, WL; CHEN, CY; LIN, YH; LIN, LY; KU, HM. 2013.Genetic diversity among Ocimum species based on ISSR, RAPD and SRAP markers. Australian Journal of Crop Science 7: 1463-1471.

COSTA, AS; ARRIGONI-BLANK, MF; CARVALHO FILHO, JLS; SANTANA, ADD; SANTOS, DA; ALVES, PB; BLANK, AF. 2015. Chemical diversity in basil (Ocimum sp.) germplasm. Hindawi Publishing Corporation: 1-9.

CRUZ, CD. 2016. Genes Software-extended and integrated with the R, Matlab and Selegen. Acta Scientiarum 3: 547-552.

DOYLE, JJ; DOYLE, JL. 1990. Isolation of plant DNA from fresh tissue. Focus 12: 13-15.

EARL, D; HOLDT, B. 2012. Structure Harvester: A website and program for visualizing STRUCTURE output and implementing the Evanno method. Conservation Genetics Resources 4: 359-361.

EVANNO, G; REGNAUT, S; GOUDET, J. 2005. Detecting the number of clusters of individuals using the software STRUCTURE: A simulation study. Molecular Ecology 14: 2611-2620.

FAO. 2017. Proposal for new work on codex standard for basil. Codex committee on spices and culinary herbs, $\mathrm{CX} / \mathrm{SCH}$ 17/03: 1-6.

KRUSKAL, JB. 1964. Multidimensional scaling by optimizing goodness of fit to a no metric hypothesis. Psychometrika 29: 1-27.

MAKRI, O; KINTZIOS, S. 2008. Ocimum sp. (Basil): Botany, cultivation, pharmaceutical properties and biotechnology. Journal of Herbs, Spices \& Medicinal Plants 13: 123 150.

MELO, RA; RESENDE, LV; MENEZES, D; BECK, APA; COSTA, JC; COUTINHO, AE; NASCIMENTO, AVS. 2011. Genetic similarity between coriander genotypes using ISSR markers. Horticultura Brasileira 29: 526-530.

MOCHE, K; LORDON, CD; FEYEM, MNM; TADU, Z; NANA, PA; FOKAM, Z; BRICHEUX, G; WOIN, N. 2014. Agromorphological characterization of two rice varieties from japan; Orysa sativa 1. and four nericas varieties in an agro-ecological zone of the town of yaounde (Cameroon); comparative study of their performances. International Journal of Current Research 6: 9941-9946.

NG, WL; TAN, SG. 2015. Inter-Simple Sequence Repeat (ISSR) Markers: Are we doing it right? ASM Science Journal 9: 30-39.

OJO, OD; ADEBAYO, OS; OLALEYE, O; ORKPEH, U. 2012. Basil (Ocimum basilicum) genetic variability and viral disease assessment in Nigeria. Asian Journal of Agricultural Sciences 4: 1-4.

PATEL, HK; FOUGAT, RS; KUMAR, S; MISTRY, JG; KUMAR, M. 2015. Detection of genetic variation in Ocimum species using RAPD and ISSR markers. 3 Biotech 5: 697707.

PEAKALL, R; SMOUSE, PE. 2012. GenAlEx 6.5: genetic analysis in Excel. Population genetic software for teaching and research - an update. Bioinformatics 28: 2537-2539.

PINTO, JAO; BLANK, AF; ANDRADE, TM; FILHO, JCFS; NASCIMENTO, LFA; SILVA, DC; ARRIGONI-BLANK, MF. 2018. Cropping season affect the performance of basil cultivars and hybrids. Bioscience Journal 34: 640-647.

POLITEO, O; JUKIC, M; MILOS, M. 2007. Chemical composition and antioxidant capacity of free volatile aglycones from basil (Ocimum basilicum L.) compared with its essential oil. Food Chemistry 101: 379-385.

PRITCHARD, JK; STEPHENS, M; DONNELLY, P. 2000. Inference of population structure using multilocus genotype data. Genetics 155: 945-959.

SAMAL, KC; JENA, RC; SWAIN, SS; DAS, BK; CHAND, PK. 2011. Evaluation of genetic diversity among commercial cultivars, hybrids and local mango (Mangifera indica $\mathrm{L}$.) genotypes of India using cumulative RAPD and ISSR markers. Euphytica 185: 195-213.

SARAN, PL; TRIPAT, HV; MEENA, RP; KUMAR, J; VASARA, RP. 2017. Chemotypic characterization and development of morphological markers in Ocimum basilicum L. germplasm. Scientia Horticulturae 215: 164-171.

SAAVEDRA, G; SPOOR, W; HARRIER, L. 2001. Molecular markers and genetic base 
broadening in Lycopersicum spp. Acta Horticulturae 546: 503-507.

SAYED, MH; MOHAMMAD, SBS; RAMISAH, MS. 2009. Analysis of Random Amplified Polymorphic DNA (RAPD) of Artemisia capillaris (Wormwood capillary) in East Coast of Peninsular Malaysia. World Applied Sciences Journal 6: 976-986.

SINGH, C; RAI, P; RAJKUMAR, BK. 2017. Recent advances in conservation of plant genetic resources. Agricultural Research \& Technology Open Access Journal 7: 1-2.

SOUZA, DCL. 2015. Técnicas moleculares para caracterização e conservação de plantas medicinais e aromáticas: uma revisão. Revista Brasileira de Plantas Medicinais 17: 495-503.

SRIVASTAVA, A; GUPTA, AK; SARKARA, S; LAL, RK; YADAV, A; GUPTA, P; CHANOTIYA, CS. 2018. Genetic and chemotypic variability in basil (Ocimum basilicum L.) germplasm towards future exploitation. Industrial Crops \& Products 112: 815-820.

WHITE, LAS; SILVA, AVC; ALVARESCARVALHO, SV; SILVA-MANN, R; BLANK, MFA; ALMEIDA-PEREIRA, CS;
NIZIO, DAC; SAMPAIO, TS; BLANK, AF. 2018. Genetic diversity of a native population of Myrcia ovate Cambess. using ISSR molecular markers. Genetics and Molecular Research 17: 1-11.

ZANELLA, CM; JANKE, A; PALMA-SILVA, C; KALTCHUK-SANTOS, E; PINHEIRO, FG; PAGGI, GC; SOARES, LES; GOETZE, M; BÜTTOW, MV; BERED, F.2012. Genetics, evolution and conservation of Bromeliaceae. Genetics and Molecular Biology 35: 10201026. 